\title{
ECONOMIC DEVELOPMENT AND SECTORAL UNIONS IN CHINA
}

\author{
ELI D. FRIEDMAN*
}

\begin{abstract}
Drawing on qualitative fieldwork in China's Guangdong and Zhejiang Provinces, the author asks how post-socialist unions respond to worker unrest and why the development of sectoral-level bargaining has been uneven in different regions of China. While Zhejiang has had relative success in establishing the organizational infrastructure for sectoral bargaining, Guangdong has had little success despite ongoing attempts by unions. The author explains variation in sectorallevel bargaining through an analysis of the different models of economic development, which are characterized as local entrepreneurialism and global integration for Zhejiang and Guangdong, respectively. Despite having different organizational forms, unions in both places suffer from a lack of credibility and capacity to enforce contracts. Given the ACFTU's ongoing focus on sectoral-level bargaining, however, experiments will likely continue in various regions and industries throughout China.
\end{abstract}

$\mathrm{H}$ ow do post-socialist unions attempt to deal with the problem of labor instability under capitalist transformation? Specifically, what-if anyidentifiable system of labor relations are unions in China pursuing, and what sorts of structural constraints do they face? My general argument is as follows: On the one hand, sectoral-level negotiation is particularly attractive to the state and unions, ${ }^{1}$ as it offers a way to improve conditions for workers within the given institutional and political parameters (namely the ban on independent unions). On the other hand, the possibility for success is highly circumscribed by both economic and political factors. Economically, diverse approaches to regional development within China present different possibilities for establishing the institutional infrastructure within which sectorallevel negotiation can take place. And politically, the weakness of official unions at the point of production renders contract enforcement tenuous to nonexistent. Thus, the post-socialist political framework encourages unions

\footnotetext{
*Eli D. Friedman is Assistant Professor at the ILR School's Department of International and Comparative Labor, Cornell University. The author thanks Peter Evans, Kim Voss, Kevin O'Brien, Ching Kwan Lee, Zongshi Chen, and Sarosh Kuruvilla for reading and commenting on earlier versions of this article. Thanks also to Tom Kochan for providing the opportunity to receive useful feedback on the paper at the MIT Institute for Work and Employment Research. Hao Zhang provided invaluable research assistance. Funding for this research was provided by the University of California's Pacific Rim Research Program.

${ }^{1}$ I have translated the official term jiti xieshang as "collective negotiation" rather than "collective consultation" to avoid confusion for English speakers.
}

ILRReview, 67 (2), April 2014. (c) by Cornell University. Print 0019-7939/Online 2162-271X/00/6702 \$05.00 
to pursue sectoral-level negotiation while simultaneously undermining the possibility of its realization.

In this article I show that sectoral-level negotiation has been a primary means by which the leadership of the All-China Federation of Trade Unions (ACFTU) has attempted to reduce labor unrest by improving conditions for workers. By focusing on the rather exceptional case of Zhejiang Province, I show that distinct regional models of economic development produce variations in the capacity of unions to engage in collective negotiation. In considering external economic conditions, I demonstrate that it is not merely control by the state- the factor most discussed in the literature-that determines union activity. Despite Zhejiangese unions being more successful than their counterparts in other parts of the country at concluding sectorallevel agreements, a crisis of legitimacy undermines the capacity to enforce such agreements.

A small amount of scholarship in English already exists on the development of sectoral negotiation in China (Liu 2010; Pringle 2011). Given that unions in southeastern Zhejiang Province have been widely hailed by the ACFTU as the most successful in this field, research has quite logically focused on this region. Empirically, I aim to intervene in three ways: First, my findings on the outcomes of sectoral-level negotiation in Zhejiang are quite different from those reported in existing research, particularly with regard to the issue of implementation. Second, I bring the development of sectoral negotiation in Zhejiang into comparative perspective through an abbreviated discussion of the experiences of unions in Guangdong-the province many scholars consider to be at the forefront of union innovation (Liu 2011; Friedman 2013). This brings into clear relief that which is peculiar to Zhejiang. Third, I draw linkages between distinct regional political economies and the divergent possibilities that are thereby produced for pursuing sector-wide collective negotiation. Concretely, I argue that patterns of capital mobility, origin of investment, levels of economic diversification, and the existence of legitimate employer associations are key factors in determining whether sectoral-level negotiation will be possible (Table 1). I contend that Zhejiang appears more likely to enact a region-based approach to collective negotiation while areas more dependent on foreign direct investment (FDI) are headed toward a firm-based approach. Finally, I show theoretically how post-socialist labor institutions are paradoxically both a facilitating and a constraining factor in the development of sectoral unions.

\section{Post-Socialist Trade Unions and Sectoral Negotiation}

As argued by Crowley and Ost (2001), Clarke, and others, post-socialist unions exhibit fundamental weakness in places as diverse as China, Vietnam (Clarke, Lee, and Chi 2007), Russia (Clarke 2005), and throughout Eastern Europe (Crowley 2004). In general, post-socialist unions remain weak because they are institutionally dependent either on the state, employers, or both. 
The state-run ACFTU is no exception. While debate continues as to whether Chinese unions suffer from a "double identity" (Chen 2003a) stuck between the state and workers-or are simply agents of the state (Lau 2003), there is consensus that they are weak (Chen 2003b) and do not actively represent workers (Taylor and Li 2007). Unions are formally subordinate to the Communist Party at all levels of the hierarchy, while at the same time they are de facto subordinate to management at the level of the firm. Management exercises significant control over selection of union representatives within enterprises (Howell 2008), even in the unusual instances where strong external pressures push for democratic elections (Yu 2008). The consequence is that enterprise-level union representatives are typically selected from a company's human resources department. Furthermore, unions do not lead strikes, therefore members are deprived of their primary form of leverage vis-à-vis employers.

But if unions in China and other post-socialist countries are structurally weak, this "does not mean the diminution of class anger" (Crowley and Ost 2001: 5). In this respect China and Vietnam are quite different from Eastern Europe in that workers are now highly mobilized, albeit outside the control of unions (Lee 2007; Chan 2010). As a result, Chinese unions have been searching for a response to generalized worker insurgency, a process that has involved many experiments among regional unions (Liu 2010; Pringle 2011), which raises the possibility of varying forms of labor relations within a single country (Locke 1992).

The umbrella of the ACFTU covers a variety of types of unions. The government has encouraged and strengthened the regionally based union federations (existing at the provincial, municipal, and often district, county, township, and street level, depending on administrative arrangements) while the nationally organized industrial unions (chanye gonghui) remain quite weak. The primary unit of the trade union system exists at the enterprise level and is supposed to be administered by an elected chair and a union committee. Most significant for this research, sectoral unions (hangye gonghui) are organizations, typically established at the municipal level, that aim to organize all of the employers in a specific industry within their jurisdiction to either engage in collective negotiation or provide legal and other types of assistance to workers.

Collective negotiation has been high on the agenda of the ACFTU for a number of years. China's employment relations were largely remade during the process of marketization, as initially marked by the enactment of the Labor Law in 1995. This law encouraged signing of labor contracts and provided the basis for experimentation with collective contracts. Unions within the structure of the ACFTU are granted the legal right to represent employees in these negotiations. Although in theory various forms of unions are empowered to engage in collective negotiation, in practice this has mostly happened at the enterprise level. Particularly in the private sector, unions have had little success in collective negotiation. Because enterprise union chairs are frequently subject to unchecked retaliation and there are no legal 
strikes, employers have few incentives to take negotiation seriously-or even to enforce the law (Cooney 2007).

Endemic legal and contractual violations in Chinese workplaces have been well documented in scholarly, journalistic, and NGO reports. ${ }^{2}$ As I will show, it is the very weakness of post-socialist trade unions at the enterprise level that resulted in non-implementation of the collective contract in the Rui'an eyeglass industry. Given that my results differ from Liu (2010) and Pringle (2011) in this regard, which conditions are likely to facilitate enforcement in the Chinese context is still unclear. Nonetheless, the ACFTU hopes that sectoral negotiation will yield better results in contract implementation.

As described by Clarke and Pringle (2009: 96), sectoral negotiation has also come into favor with post-socialist unions in Russia and Vietnam. Sectoral negotiation is a particularly attractive option when membership mobilization is off the table and maintenance of good relationships with the state and employers is of paramount importance. Based on my own research in China, this is the case for several reasons: First, establishing sectoral standards can be in the interests of a segment of employers. Second, such a project can gain support from the local and national government, particularly if it has the effect of rationalizing labor relations and reducing conflict. And finally, because such an approach to negotiation is typically conducted in a top-down manner workers will likely remain demobilized. Especially in an environment in which unions have good access to the state bureaucracy but cannot depend on their membership as a source of political power, an administrative approach to collective negotiation is much more feasible. The ACFTU's commitment to increasing the prevalence of sectoral negotiation was indicated by the 2006 promulgation of "Advice on Conducting Regional Sectoral Collective Negotiation." This official document established guidelines to determine when such an approach is appropriate and how to select representatives as well as the content and process of bargaining (Zhang and Shi 2012: 52). Sectoral negotiation is therefore a major trend worthy of further investigation.

Although research on such topics in China is just now emerging, research exists on the preconditions for successful sectoral bargaining in wealthy liberal democracies. In analyzing collective bargaining in the Organisation for Economic Co-operation and Development (OECD), Traxler identified three key factors in the development of multiemployer bargaining: strong unions, strong employer associations, and a supportive state (1998: 213). In China, illegitimacy of unions creates problems with "vertical coordination" (Traxler 2003: 197) — that is, gaining acceptance from the rank and fileimplying that the latter two categories will likely be of greater relevance. More recent literature from the West has analyzed the effects of neoliberal

${ }^{2}$ For one prominent recent example, see SACOM, accessed at http://sacom.hk.report-apple-fails-inits-responisbility-to-monitor-suppliers-2/ (February 26, 2013). 
globalization on established multiemployer bargaining systems and called into question the sustainability of such arrangements (Lindbeck and Snower 2001). Although decentralization of bargaining has appeared in many places, national-level sectoral bargaining systems have responded to increasing competitive pressures in various ways (Katz 1993; Marginson, Sisson, and Arrowsmith 2003).

Although state capacity is a key factor in determining the development of sectoral negotiation, it is crucial to have well-established employer associations in place. Since employers tend to have less need than do workers to act collectively to realize their interests (Offe and Wiesenthal 1980), the question is what are the conditions under which employers will seek to associate and bargain collectively with labor. Behrens (2004) has argued that strong unions, state action, or collective-action problems are key factors in encouraging employer associations to act (and that any one of these factors may be sufficient).

Particularly in China, which does not have strong unions, issues of employer collective-action problems are crucial. China has two nationally organized employer associations, the China Enterprise Confederation-China Enterprise Directors Association (CEC-CEDA) and the All-China Federation of Industry and Commerce (ACFIC). In part because of a lack of legitimacy among employers (Ma 2011), these organizations have infrequently played a role in facilitating sectoral negotiation. While there have been moments when such organizations have behaved in a corporatist manner (Pearson 1994), they are certainly not the type of representative organizations found in other countries. As a result, individual employers (Traxler 1993: 686) or local employer organizations such as those in Zhejiang (see below) may be more likely to play an important role in establishing multiemployer bargaining.

An increasingly globalized economy is likely to pose challenges to the sustainability of employer associations-and therefore sectoral agreements-as capital has become increasingly mobile. In this sense, distinct approaches to development present different obstacles and opportunities for the realization of sectoral negotiation.

\section{A Distinct Path to Prosperity in Zhejiang}

The dominant narrative in explaining sustained growth in China is that FDI and massive state-owned enterprises have sustained the economy, while domestic private industry has played an auxiliary and relatively minor role (Huang and Khanna 2003: 75). While some recognize the spatial and sectoral unevenness of FDI (Broadman and Sun 1997), the overall consensus is that foreign investment is good for growth (Chen, Chang, and Zhang 1995) and, despite possible political drawbacks (Eng 1997; Gallagher 2002, 2005), that it is a fundamental part of the story of development in China (Tseng and Zebregs 2003). 
Table 1. Models of Development

\begin{tabular}{lll}
\hline & Local entrepreneurialism (Zhejiang) & Global integration (Guangdong) \\
\hline $\begin{array}{l}\text { Origin of investment } \\
\text { Capital mobility }\end{array}$ & Local & Transnational \\
Economic diversification & Low & High \\
& Low (single commodity village) & $\begin{array}{c}\text { High (diverse manufacturing, } \\
\text { public sector, finance, } \\
\text { trade, service, etc.) }\end{array}$ \\
Employer associations & Full membership/high legitimacy & \begin{tabular}{c} 
Segmented/nonexistent \\
\hline
\end{tabular}
\end{tabular}

Indeed, total FDI more than doubled from US $\$ 40.3$ billion in 1999 to $\$ 92.4$ billion in 2008, ${ }^{3}$ making China the largest FDI recipient in the world. But this narrative about China's development does not reflect the "local entrepreneurialism" that has driven growth in Zhejiang. Places that have received more attention in the literature such as Guangdong are in fact characterized by deep "global integration." The key factors that define these two models and that determine the likelihood of sectoral negotiation are summarized in Table 1. We will see that local entrepreneurialism in Zhejiang results in greater capacity to establish the institutional framework for encouraging sector-wide negotiation. The story of the "global integration" path to development has been written about extensively (Huang 2003), but the broad outlines are worth re-emphasizing in order to bring the distinct character of Zhejiang's development into clearer focus. Guangdong Province best exemplifies this model.

Following Deng Xiaoping's rehabilitation and rise to power, the government formally announced the beginning of market reforms in 1978. By 1980, four special economic zones had been established in China, three of which were in Guangdong Province. These special zones, along with a number of "coastal open cities" that were established in 1984, provided foreign investors with a highly favorable regulatory environment-a setup that produced years of strong growth (Pak 1997). A massive influx of migrant workers from the countryside (Solinger 1999) provided a cheap and flexible source of labor, and the Pearl River Delta quickly came to be the country's top destination for FDI (Chen, Chang, and Zhang 1995). By the early 21st century, the region had become the world's premier manufacturing center, a development that allowed for a radical reconfiguration of global supply chains (Lichtenstein 2009).

Of crucial importance is the extent to which this process was driven by foreign investors (Gallagher 2005), particularly those in the Chinese communities in Hong Kong, Taiwan (Hsing 1998), and Southeast Asia. This heavy reliance on foreign investment caused many observers to come to the conclusion that China's development as a whole has not been driven by domestic private firms. If by 2007 more than $61 \%$ of Guangdong's total

${ }^{3}$ PRC Ministry of Finance. Accessed at http://www.uschina.org/statistics/fdi_cumulative.html (September 10, 2009). 
Table 2. Foreign Investment in Zhejiang, 2007

\begin{tabular}{lcc}
\hline Location & $\begin{array}{c}\text { Value of utilization of } \\
\text { foreign capital (US\$) }\end{array}$ & $\begin{array}{c}\text { Value of utilization of } \\
\text { foreign capital per capita (US\$) }\end{array}$ \\
\hline Northeast & & \\
Hangzhou & $5,580,590,000$ & 830 \\
Ningbo & $4,501,070,000$ & 797 \\
Shaoxing & $2,365,160,000$ & 542 \\
Jiaxing & $3,455,120,000$ & 1,026 \\
Southeast & & \\
Wenzhou & $1,049,444,000$ & 137 \\
Jinhua & $373,352,000$ & 81 \\
Taizhou & $816,810,000$ & 144 \\
\hline
\end{tabular}

Sources: Zhejiang tongii nianjian 2008. Beijing: zhongguo tongii chubanshe, p. 564; Zhejiang Economic Census Yearbook 2004. Beijing: China Statistics Press, pp. 7-16.

industrial output derived from foreign-owned enterprises, that number was only $26.6 \%$ in Zhejiang.

A significant body of literature on labor in FDI-fueled Guangdong already exists (Lee 1995, 1998, 2007; Chan 2001; Thireau and Hua 2003; Pun 2005; Pun, Chan, and Chan 2009) and, in particular, concerning the Pearl River Delta. The global integration of this region has produced a certain set of possibilities for labor. Briefly, the local state and unions have encountered severe obstacles in disciplining highly cosmopolitan and footloose capital or persuading employers to participate in interest-aggregating business associations. Despite the desire of unions in the region to pursue collective negotiation at the sectoral level, they have had little success. As a result, collective negotiation has generally proceeded at the enterprise level.

Although not well known internationally, Zhejiang's local entrepreneurialism stands in contrast to the typical story about development in China (Y.-L. Liu 1992; Nee and Opper 2012). Zhejiang's output of RMB313 per capita in 1978 made it only the thirteenth wealthiest province in China, ${ }^{4}$ but by 2009 that number had skyrocketed to RMB44,383-just RMB200 behind the front-runner, Jiangsu. ${ }^{5}$

Perhaps the most significant indicator of the extent to which Zhejiang differs from the global integration model is the percentage of output that derives from foreign-invested firms. In 2003, a modest $20.1 \%$ of output in Zhejiang came from foreign firms, and that number crept up to $26.64 \%$ by 2007. ${ }^{6}$ While being one-quarter of the economy is clearly of significance, it pales in comparison to Guangdong's massive reliance on foreign investment. In 2007, $61.05 \%$ of output in Guangdong came from foreign firms. ${ }^{7}$

\footnotetext{
${ }^{4}$ Accessed at http://www.zhejiang.gov.cn/gb/node2/node1619/node1622/userobject13ai697.html (September 10, 2009).

${ }^{5}$ Zhongguo tongji nianjian 2010. Beijing: zhongguo tongji chubanshe.

${ }^{6}$ Zhejiang tongii nianjian 2008. Beijing: zhongguo tongji chubanshe.

${ }^{7}$ Guangdong tongji nianjian 2008. Beijing: zhongguo tongji chubanshe.
} 
But when we dip below the provincial level of aggregation in Zhejiang, the story becomes a bit more complex. The northeast part of the province, with its close proximity to Shanghai, is much more integrated into national and international circuits of capital, commodities, and labor. The southeast, in contrast, has been historically isolated and dependent on indigenous enterprise. One consequence of this variation is that the amount of foreign investment in the two regions has differed remarkably.

Physical separation, historically poor infrastructure, and a relatively low international profile make it unsurprising that the city in the southeast that has had the most success with FDI, Taizhou, has foreign investment per capita that is only slightly more than one-tenth of Jiaxing's. The three southeastern municipalities are exemplary of local entrepreneurialism and are thus the focus of this research.

The distinctive model of development found in southeastern Zhejiang started in the city of Wenzhou (Bramall 1989). As the Cultural Revolution drew to a close, and with political leadership unable and/or unwilling to stop it, ${ }^{8}$ experiments with household-based commodity production began to take off. Whereas in 1980 only $1 \%$ of industrial output in Wenzhou came from private firms, by 1988 that number jumped to an astonishing $41 \%$ (A. P. Liu 1992: 703). Between 1981 and 1985 the municipality's gross industrial output increased by 130\% (Forster 1990: 57). With firms rarely exceeding 100 employees, and more typically employing around 35 (Parris 1993: 247) (all of whom would be hired from the locality), deep social integration was typical between workers and management in Wenzhou firms (Chen 2008). An additional significant feature of this model was that villages in the region came to specialize in a single commodity (e.g., buttons, lighters, eyeglasses, handbags, etc.) so that a large number of small enterprises producing the same good would be highly geographically concentrated. Although external competition eventually forced changes in the internal structure of firms, especially leading to an increase in hiring of migrant labor, local enterprises remain the bedrock of the local economy (Warner 1995; Wright 2000; Tsai 2002; Tseng and Zebregs 2003; Wang 2004; Wu 2004; Wei, Li, and Wang 2007; Yu, Xu, and Jiang 2007).

\section{Methods}

This article is based on extensive qualitative fieldwork conducted from 2008 to 2010. While my time was not spent continuously in one place, I was based in Guangzhou for approximately ten months, with six weeks spent in Wenzhou, Zhejiang Province. The focus of the article is the Rui'an Eyeglass Sectoral Union in Zhejiang. ${ }^{9}$ For comparative context, I briefly discuss examples of sectoral union activity in Guangzhou. As indicated above, much

\footnotetext{
${ }^{8}$ Tsai (2002) and Zhang and Liu (2013) have written in detail about how local officials provided necessary cover for the development of private capital markets in Wenzhou.

${ }^{9}$ Rui'an is a county-level city within the jurisdiction of Wenzhou.
} 
of the research on labor in China has focused on Guangdong. Including Guangzhou as a touchstone will help in contextualizing the Zhejiang case and will illustrate the emerging diversity in forms of labor relations. In both places I examined sectoral unions that were considered exemplary by union officials, with the understanding that the most successful cases would reveal something about union capacity, aspirations, and future possibilities.

I selected these cases for specific reasons. Zhejiang and Guangdong are two of the wealthiest provinces in China, as well as the most industrialized. They also have some of the highest levels of labor unrest. As a result, it is reasonable to assume that these provinces would be among the first to develop new industrial relations systems. Additionally, they are quite representative of the distinct models of development presented in Table 1-global integration in the case of Guangdong and local entrepreneurialism in the case of Zhejiang.

Data presented in the case studies are collected from in-depth interviews and informal conversations with workers, managers, officials from the union, employers' associations, and government, as well as from official documents, media reports, and publicly available statistics. In Rui'an, I interviewed managers from ten eyeglass firms and one dozen workers, whom I approached independently. I also interviewed a deputy chair of the Rui'an Federation of Trade Unions, one official from the Rui'an Labor Bureau, and the chair and deputy chair of the Eyeglass Employers Association. In Guangzhou I interviewed all three of the full-time staff of the construction union, the chair of the sanitation union (with whom I also spent several days on a tour of the United States), and ten street cleaners whom I encountered independently of the union. In addition, I interviewed and spent countless hours with high-level officials from the Guangzhou Federation of Trade Unions, which resulted in ethnographic data that are difficult to quantify.

A highly qualitative, microlevel approach is the type best suited for this study, particularly because of the Chinese political context. Often a tenuous relationship holds between what union and government officials say and what actually takes place on the ground. As a result, a comparison of formal bargaining arrangements in different regions may reveal important trendsbut until they are empirically verified on the ground, one cannot be sure of their validity. What this research lacks in representativeness and generalizability it makes up for in empirical accuracy. Additionally, it allows one to see the aspirations of employers and officials from the union and government, and how those aspirations are frequently confounded in practice.

\section{Sectoral Unions and Global Integration}

The development of sectoral unions generally in Guangdong Province, and Guangzhou in particular, has been halting at best. But it has not been for lack of effort - the reform-minded chair of the Guangzhou Federation of Trade Unions (GZFTU) until 2012, Chen Weiguang, had pursued sectoral negotiations since at least 2007. And yet, Chen complained that sectoral 
negotiation was greatly constrained by the fact that they do not have a "partner"- that is, there is no party with which they can negotiate collective contracts. One of the vice-chairs of the GZFTU was quite explicit about the problem when describing why in Guangzhou the unions were only focused on collective negotiation at the enterprise level: "Our sectoral unions are not mature, and ... the employer associations are not mature. They [employer associations] are even less mature! So we don't have an opponent."10

Although Guangdong has employer associations, they are generally split along lines of nationality (e.g., the United States, European Union, Hong Kong, Taiwan, etc. each has its own chamber of commerce). Some of these associations have been able to coordinate political lobbying efforts-most importantly in 2010-11, when a concerted effort from the Hong Kong Chamber of Commerce successfully derailed a new piece of labor legislation in Guangdong. Nonetheless, this political capacity is quite distinct from the ability to represent all, or a significant majority of, employers in a given industry in collective bargaining. The official associations that do exist either do not have adequate membership or are seen as illegitimate by employers. Under such conditions, it is incredibly difficult to establish wage agreements for an entire sector.

According to GZFTU leaders, the two best examples of sectoral unions in the province were the construction and sanitation workers' unions. Nevertheless, neither of these unions had succeeded in negotiating collective contracts or setting any kind of industry standards. One cadre from the construction union argued that "the market economy is a presupposition, so there isn't any need to intervene here [by negotiating wages]." 11 This union's activities were restricted to passing out legal information at construction sites.

Efforts by the sanitation workers' union had been similarly stymied. In the mid-2000s the government deregulated the industry, and contracts were given to a variety of private companies. By 2008, there were more than 600 companies involved in sanitation work in Guangzhou, including both domestic and foreign-owned firms. ${ }^{12}$ With privatization came worsening conditions for many workers, and in spring 2008 street cleaners in one of the industrial districts of Guangzhou went on strike. Shortly thereafter, the GZFTU decided to establish the Sanitation Workers Sectoral Union. But despite lots of attention from union leadership, the sectoral union was unable to address ongoing rights violations in the industry, which became apparent when a succession of wildcat strikes took place from 2009 to 2013. At the time of writing, the municipal government has become involved in trying to establish standards in the industry, a task the union was unable to accomplish.

\footnotetext{
${ }^{10}$ Field notes, October 2009.

${ }^{11}$ Interview, April 2009.

${ }^{12}$ Field notes, December 2008.
} 
Table 3. Wage-Only Collective Contracts (WCC), 2006

\begin{tabular}{lcccc}
\hline Province & $\begin{array}{c}\text { Total } \\
\text { workforce }\end{array}$ & $\begin{array}{c}\text { No. of enterprises } \\
\text { covered by sectoral WCC }\end{array}$ & $\begin{array}{c}\text { No. of workers covered } \\
\text { by sectoral WCC }\end{array}$ & $\begin{array}{c}\text { \% of workers covered } \\
\text { by sectoral WCC }\end{array}$ \\
\hline Zhejiang & $31,723,800$ & 6,311 & 346,413 & 1.1 \\
Guangdong & $52,500,900$ & 4,062 & 84,889 & 0.16 \\
\hline
\end{tabular}

Source: Zhongguo gonghui tongii nianjian 2007. Beijing: zhongguo tongji chubanshe.

Furthermore, Guangzhou unions did not even attempt to develop sectoral unions in manufacturing until 2011, which is somewhat surprising given the centrality of this sector to the local economy. In general, one would expect organizing sectoral agreements in manufacturing to be more difficult than in the service sector or construction, since the latter are place specific. It is thus all the more surprising that more robust sectoral negotiation has developed in the seemingly mobile manufacturing sectors of Wenzhou.

\section{Labor Relations in Zhejiang}

Official statistics indicate that Zhejiang Province has been more successful with sectoral-level unionization and wage negotiation than has Guangdong (Table 3). In addition to the numbers indicated in the table, it is worth noting that of the total number of workers covered by any sort of wage-only collective contract, $9.4 \%$ of those in Zhejiang are covered by sectoral-level agreements, more than double the $4.1 \%$ covered in Guangdong. This is strong evidence that enterprise-level negotiation is more prevalent in Guangdong than in Zhejiang, while sectoral negotiation is more prevalent in Zhejiang. And the advances with sectoral-level negotiation in Zhejiang would not have been possible without the existence of the province's unusual employer associations.

\section{Local Employer Associations}

Although it has been largely ignored in the English-language literature, a significant amount of research has been conducted by Chinese scholars on the development of independent employer associations in Zhejiang (Wang 2004; Wu 2004; Yu, Xu, and Jiang 2007). While these organizations still must be formally "attached" (guakao) to a parent state organ, their organizational structure and decision-making procedures are formally autonomous. They do not receive any funding from the state but, rather, are supported by membership dues. Some exceptions notwithstanding, their leadershipselection process is usually internally determined. As one indication of this trend, in $200377 \%$ of employer associations in Wenzhou reported that their chairs were selected according to their own internal rules (Yu, Huang, and Fang 2004: 37).

"Local entrepreneurialism" is reflected in the membership of employer organizations that are endowed with high levels of social capital. In describing 
the process of setting up the eyeglasses employer association in Rui'an, the organization's director said that since everybody already knew everybody, it was a relatively straightforward procedure. ${ }^{13}$ Of the nearly 100 eyeglasses manufacturers in the county-level city, only one is a joint venture (with Taiwanese investors), and none are fully foreign-owned firms. Moreover, only two of the Chinese-owned enterprises are owned by people from cities other than Rui'an. ${ }^{14}$ A trade union official in Rui'an commented that members of the employer association would listen to and obey their chair since "their relationships are like brothers." ${ }^{15}$ The thick social networks tie together not just employers to other employers but also the business association to the state. With retired government officials sometimes serving as officers in the employer association, it is often the case that representatives from each group have long-standing relationships with one another. These dense social ties were apparent at the numerous meals I attended in which various employers and officials from the employer association and government would interact socially with one another. What this means is that the state and union may have not just administrative but also social resources at their disposal when they interact with employers.

\section{Sectoral-Level Negotiation in Zhejiang}

Starting in 2004, trade unions in certain industries in southeast Zhejiang began to successfully conclude sector-wide wage agreements that cover nearly all enterprises within a given city. This model has been most successful in relatively labor-intensive industries in which a large number of small local employers in one particular industry are concentrated in a particular district. While the trade union has played a key role in signing such agreements on behalf of workers, the impetus for setting wage standards has come largely from employers and the state after they became concerned about high turnover and excessive labor conflicts. In order to address this problem, an organizational innovation taking the form of sectoral trade unions was necessary. The establishment of sectoral unions mirrored the already existing employer association, thus creating the framework for multiemployer bargaining.

At least two scholars writing in English have discussed sectoral-level wage negotiations; both focus on industries in southeast Zhejiang. ${ }^{16}$ The broad outlines of the experiences of the Zeguo Water Pump Sectoral Union (Liu 2010) and the Wenling Woolen Sweater Sectoral Union (Pringle 2011) are quite similar to what I found with the Rui'an Eyeglass Sectoral Union. But there is a crucial difference: while both Liu and Pringle were cautiously optimistic that these unions had successfully bargained and implemented

\footnotetext{
${ }^{13}$ Interview, July 2009.

${ }^{14}$ Interview, December 2009.

${ }^{15}$ Field notes, July 2009.

${ }^{16}$ Some literature can also be found in Chinese, e.g., Chen and Huang 2008; Zhu 2008.
} 
collective contracts, I uncovered something rather different. If the official story in Rui'an was remarkable in its parallels with these earlier cases, it was the case that the agreement that was supposed to regulate eyeglass production was not actually being implemented. And yet my research, combined with these earlier studies, confirms that as an institutional form sectoral-level negotiation remains a possibility in the local entrepreneurial environment of Zhejiang, while such a setup is severely challenged by global integration in the Pearl River Delta and other regions (Chen and Huang 2008; Zhu 2008).

\section{The Rui'an Eyeglass Sectoral Union}

Rui'an is a county-level city of 1.17 million residents that is administratively subordinate to Wenzhou municipality. ${ }^{17}$ As one of the more industrialized areas of Wenzhou, it exemplifies the "Wenzhou model" of dependence on small family-owned enterprises. Rui'an is best known for its productive industries, including shoes, textiles, handbags, small consumer goods, and the like. The focus of my research is the eyeglass sector that is centered in the small township of Mayu that employs more than 12,000 workers. For a number of years the government of Rui'an has been intent on becoming the pre-eminent eyeglass manufacturing center in the world, and they have begun to actively recruit international eyeglass brands to establish offices in the city.

After the first eyeglass factory was established in 1978, the sector in Rui'an grew quite rapidly for a number of years. ${ }^{18}$ Relying on the renowned Wenzhou-style family-based marketing networks, these producers first conquered domestic markets and then expanded internationally. By the late 2000s, sales from the Rui'an eyeglass industry totaled more than 10 billion $\mathrm{RMB}$, accounting for half of all nationwide eyeglass sales, and the Eyeglass Employers Association estimated that $60 \%$ of all eyeglasses worn in China were produced in Rui'an.

But with more entrants to the market during the 1990s came increased competition for skilled labor. Individual skilled workers began pitting employers against one another in an effort to increase their wages. Smaller, younger enterprises did not have the financial or knowledge-based resources to conduct the comprehensive worker training programs that the larger and more established companies held. One result of this was that these smaller enterprises began to pilfer skilled workers from other enterprises by offering marginally higher piece rates. In a formal address, the chair of the Eyeglass Employers Association presented this as a very serious problem:

\footnotetext{
172008 nian rui'an shi guomin jingji he shehui fazhan tongji gongbao (2008 report on Rui'an's economic and social development). Accessed at http://www.ratj.gov.cn/tjgb/2008.htm (October 15, 2009).

${ }^{18}$ The data in the proceeding section are derived primarily from official union documents.
} 


\begin{abstract}
The need for technical personnel and skilled workers has been steadily increasing within the industry, and using high salaries in hiring has been an inevitable decision for enterprises. "Cutting the ground out" from one another is already not a new phenomenon, and this has led to lack of order and chaos in enterprise employment. ... According to the social security authorities, labor conflicts have been occurring continuously in the industry, which has led to a worsening of the employment environment, and the positive development of the industry has been restricted. ${ }^{19}$
\end{abstract}

Thus, in 2001 two of the largest eyeglass firms in Rui'an took the initiative in trying to establish sector-wide standards, and they began to appeal to the Eyeglass Employers Association for assistance.

The Rui'an Eyeglass Employers Association was previously a formal statesponsored organization. Eventually, the local government decided to "give them freedom," 20 which meant greater organizational autonomy but also implied responsibility for raising their own operating expenses. The association now operates as an independent organization and is $100 \%$ dependent on membership dues for its operations. Often new laws and regulations that are of relevance to the industry are disseminated through the association. As one official from the local labor department said, "These are things the government used to do, but they gave this responsibility to the association."21

The push for a sector-wide standardization of wages was one of the most significant tasks taken on by the association, and it required intense negotiations among firms. The instability in the labor market was most problematic from the point of view of large employers, ${ }^{22}$ since smaller enterprises would frequently poach their skilled workers. As a sympathetic employer explained, "Every year in the busy season, workers would go on strike, and nearby manufacturers would not hesitate to use high salaries to poach skilled workers. If we did not sit down and bargain, it would be difficult for the entire eyeglass industry to continue on." ${ }^{23}$ Following the lead of the Wenling Woolen Sweater Sectoral Union, the decision was made to establish an eyeglass sectoral union. Leaving no doubt about where the initiative came from, the official document approving the establishment of the Rui'an Eyeglass Sectoral Union is addressed to the Eyeglass Employers Association.

The next item of business was holding collective wage negotiations. The union conducted an investigation into wage levels in the various eyeglass enterprises, speaking with managers and workers and conducting a survey. The information was analyzed, and the union put forth a proposal for unified piece rates for 318 specific work operations. After soliciting comments and holding a few negotiation sessions, in September 2005 the respective

\footnotetext{
19"Jianli hangye zhidaihui, gongchuang hexie laodong guanxi" (Establish sectoral worker representative congress, build harmonious labor relations together), April 29, 2009.

${ }^{20}$ Interview, July 2009.

${ }^{21}$ Interview, July 2009.

${ }^{22}$ It is not coincidental that the CEO of one of the largest manufacturers in the city, Chen Chengwei, was also the chairman of the Eyeglass Employers Association.

23 "Zhejiang goujian hexie laozi guanxi chutan" (First explorations in Zhejiang's construction of harmonious labor relations), ban yue tan, February 5, 2008.
} 
chairs of the employer association and the sectoral union signed a final contract.

Although appearing reluctant to discuss disagreements among employers, the chair of the association did admit that some small employers refused to participate in the sectoral wage agreement. Since the employer association is not a government agency, it could not "force them to sign."24 Additionally, he conceded that of the 130 eyeglass manufacturers in Rui'an, about 30 are not members of the association. That being said, cooperation between the employer association, trade union, and perhaps most important, government and Communist Party officials, eventually resulted in a legally binding collective wage agreement.

The actual content of the contract is very limited, as it consists of only five articles. Article 1 simply states the two-year time period during which the contract is in effect. Article 2 is the meat of the contract and says that workers will be remunerated according to the piece rate established in the "2009 Rui'an City Eyeglasses Employers Association Enterprise Piece-Rate Form.” Article 3 says that workers must be paid on time but if an enterprise is having "difficulty," payment of wages can be delayed after consultation with the union. Article 4 states that the contract is legally binding. Article 5 specifies that disputes should be handled according to the law.

Four years after the conclusion of the collective wage agreement, the unions, government, and employers were very pleased with the results. The official story is that previous illegal actions on the part of employers, such as holding employees' ID cards or taking deposits, have been eliminated. Turnover was greatly reduced, which stabilized production. In an official report from 2010 the union claimed, "Since enacting collective wage negotiation in Rui'an's eyeglass sector in 2005 , the entire industry has had peaceful employment, smooth production, and employees' wages have increased with the development of the economy and the enterprise: 'a rising tide has lifted all boats." 25 The report continued, "Collective negotiation in the eyeglass enterprise has served as a positive model to help spur the development of sectoral wage negotiations in Wenzhou municipality." ${ }^{26}$ Somewhat counterintuitively, the chair of the Eyeglass Employers Association stated, "The boss can't just call the shots ... [and he or she] can't just fire people at will." ${ }^{27}$ Rather, employers and workers alike were bound by the official process of negotiation. Not only were local officials satisfied, they received separate visits from the deputy chair of the national-level Financial, Commercial, Light Industry, Textile and Tobacco Workers' Union and a member of the Zhejiang People's Consultative Congress. Despite this official praise there was just one problem: the contract was not being enforced.

\footnotetext{
${ }^{24}$ Interview, July 2009.

${ }^{25}$ Cixi Federation of Trade Unions. Accessed at http://zgh.cixi.gov.cn/art/2010/6/24/art_9476 _423891.html (January 2013). 


\section{Nonenforcement}

During my first brief foray into the field in Rui'an, I only interviewed officials from the labor department, the trade union, and the employer association. But as soon as I began to meet with other employers in the area it became clear that things on the ground were not as I had been led to believe. The first outside interview I conducted was at Huangwei Eyeglasses. Not only had the general manager never heard of the sectoral agreement, he stated unambiguously that Huangwei did not use piece rates at all (as dictated by the collective agreement) but, rather, hourly rates.

As I interviewed manager after manager over the next several weeks, I discovered that not only were very few employers abiding by the agreement, hardly any of them had even heard of it. Managers from the largest enterprises with up to 500 workers and those from small firms with only 80 employees were equally confused by my inquiries about collective wage negotiations. Nor were they familiar with the "2009 Rui'an City Eyeglasses Employers Association Enterprise Piece-Rate Form," the supporting document that set common piece rates for the entire industry. Even managers from Zhilian Eyeglasses (one of the two large enterprises that promoted the idea of a sectoral collective wage agreement) told me during a factory visit that their wages were higher than those of other neighboring factories, indicating that they were not abiding by any industry standards.

The production workers (essentially all of whom were migrants) were equally unaware of the existence of such an agreement. In my many evenings hanging out with workers at the pool tables in Mayu's industrial zone, I quickly learned that the topic of collective contracts and trade unions would elicit no response. On my first night, I asked a few workers from a nearby glasses factory about the collective contract. Not only were they unaware of the existence of a collective contract, they said that in their factory workers did not sign contracts at all but, rather, that it was based on "trust." 28

Additionally, and in contrast to what Rui'an union officials had told me, very few of the enterprises had established a union branch. Many employers claimed that unions were only set up in the larger enterprises because they are more "by the books" (zhenggui). One manager from a small enterprise with fewer than 100 employees had this to say about a union branch: "At the moment we don't have one; we can't set it up," 29 indicating that establishing a union required resources that smaller enterprises do not have. While the municipal-level union officials had claimed that they used the negotiations over the collective wage agreement as an opportunity to establish more enterprise-level union branches, I did not find any evidence of new organizing initiatives.

The firms that I had contact with all confirmed that they were members of the employer association. As the epicenter of Rui'an's eyeglass industry,

${ }^{28}$ Field notes, December 2009.

${ }^{29}$ Interview, January 2010. 
Mayu had the highest level of social capital, and it was where the activities of the employer association were focused. Employers' assessments of the association varied from mild to enthusiastic support. Most commented on the association helping them to learn about new policies and new market opportunities, but nobody mentioned its role in establishing industry standards. All members had to pay dues that were adjusted based on the size of the enterprise. Thus, employers' lack of familiarity with the collective wage agreement cannot be attributed to their nonparticipation in the employer association.

The lack of enforcement of sectoral wage standards was further highlighted by employers' frequently expressed angst over one of the main problems that the agreement had originally set out to resolve: high turnover of skilled workers. Senior managers from both small and large enterprises complained about workers jumping ship. One manager from an enterprise with 110 workers described the problem as "very serious" and "very troublesome" but said that "there is nothing to be done.... [Workers] have freedom." ${ }^{30}$ Large employers were even more agitated about the pilfering of workers. $\mathrm{Wu}$, a veteran of more than 20 years in the eyeglass industry, had worked for the two largest eyeglass manufacturers in the city, Zhilian and Huakai. Both enterprises have workforces exceeding 300. Wu described in detail how these two enterprises are among the only factories that have extensive worker-training programs. During the busy season, however, small enterprises will try to offer marginally higher piece rates to their skilled workers to lure them away. According to $\mathrm{Wu}$, the first question these small enterprises ask potential employees is, "Have you worked for Zhilian or Huakai?," 31 as this is a strong indication of how well trained they are. In general, nobody claimed that the problem of jumping ship had improved in recent years (in the time since the conclusion of the collective wage agreement), with some saying that things had not changed and others expressing that the situation had gotten much worse.

In sum, it is clear that the sectoral-level wage agreement that was so highly touted by officials from the Rui'an Federation of Trade Unions and the Eyeglass Employers Association was not being enforced. Despite the exertion of extensive efforts by official representatives, the agreement exists on paper only.

\section{Discussion}

The emergence of sectoral-level wage negotiation has been possible in the seemingly unlikely terrain of small-commodity production in Zhejiang because of the region's distinct model of development, referred to as "local entrepreneurialism." In particular, the origin of investment, level of economic diversification, and existence of legitimate employer associations are

\footnotetext{
${ }^{30}$ Interview, January 2010.

${ }^{31}$ Field notes, December 2009.
} 
key determinants. I have demonstrated that Zhejiang, and in particular the southeastern part of the province, has been largely dependent on indigenous entrepreneurs in their process of development. Although the local state's degree of "autonomy" is up for debate, the local character of capital allows for it to be highly embedded (Evans 1995). In addition, the high level of social capital among employers has provided the union with a representative bargaining partner in the form of local employer associations. Given the high density of a particular industry in a very small geographic region, township-level governments are highly dependent on the sustainable development of the given industry in order to maintain their tax base. These conditions do not hold in many other places in China-notably in Guangdong, where unions cannot bargain with highly cosmopolitan and fractured employers at the sectoral level.

And yet the question remains as to why the sectoral agreement in Rui'an has not been enforced, despite its being in the interest of the local government and a significant segment of employers. A major cause of nonenforcement seems to be a crisis of representation in the union. The Rui'an Eyeglass Sectoral Union never involved or substantively consulted with its membership in the negotiation effort. To refer to eyeglass workers in Rui'an as "members" is even a bit of an overstatement, as they did not pay dues, were not aware of the fact that they were members, and were completely unaware that representatives were acting on their behalf. The union did exert quite a lot of effort in negotiating the contract, but this performance was directed at other government agencies, the employer association, and higher levels of the trade union, not toward the workers. As a result, there was no pressure from below on employers to abide by the agreement. Indeed, it's not clear that workers would have supported the agreement, as the rather anarchic status quo could potentially be beneficial for skilled workers. The union would have to reach an agreement amenable to its members in order for them to have the impetus to monitor implementation within the enterprise.

Why then, if the Rui'an contract is not being enforced, is this research significant? Whether or not enforcement is a problem, the institutional response of the union is quite different in Zhejiang from what it is in Guangdong and other places in China. We can see in Rui'an that unions are groping about for an institutional response to labor market instability. Even though the benefits of such a response failed to materialize in Rui'an, evidence indicates that unions have been more effective in neighboring towns (Liu 2010; Pringle 2011). While Zhejiang unions are developing the institutional framework for regularized sectoral-level negotiation, Guangdong unions have, despite their efforts, failed in this endeavor.

\section{Conclusion}

Although China's system of labor relations is quite distinct from that of liberal democracies, existing literature on sectoral bargaining in liberal democracies is a useful starting point for understanding the situation in China. 
As with the European cases, we can see how, in China, state capacity and collective-action problems for employers can serve as the impetus to establish sectoral negotiation. Additionally, we can witness the crucial role that representative employer associations play in China as they do elsewhere. But in addition to the questions of organizational interest and capacity that have received more attention in the literature, I have drawn attention to the way in which external economic conditions can either encourage or inhibit the realization of such arrangements. In particular, patterns of capital mobility, origin of investment, and levels of economic diversification in a particular region are key variables that can facilitate or restrict the capacity to establish sectoral agreements. Such structural conditions are likely to be important in settings beyond China, and they may be increasingly important in an era in which national economies are highly subject to global forces.

Perhaps more specific to the post-socialist context, unions in such countries face distinct political challenges when it comes to the issue of enforcement. We have seen how sectoral-level collective negotiation is both attractive and possible for such unions: attractive in the sense that they can avoid mobilizing membership and possible in that—under the right economic conditions-the administrative power of the union and state can be deployed in reaching agreements with employer associations. And yet, it is precisely unions' deep integration with the state that allows such agreements to come into existence while simultaneously undermining the possibility of their enforcement. In the case of the Rui'an Eyeglass Sectoral Union, workers were completely excluded from the process of contract negotiation and thus had no capacity to play a political role in contract enforcement.

To return to Traxler (1998), we see that the eyeglass industry in Rui'an has a supportive state and a strong employer association, thus suggesting that multiemployer bargaining might be possible. But the arrangement collapses without the final actor-a strong union. (Recall that the union in this case was started by the employers.) This then raises the question of just how strong a union needs to be in order to for multiemployer bargaining to be effective. Similarly, Behrens (2004) argued that employers will tend to associate in response to strong unions, state initiative, or collective-action problems. While the latter two conditions pushed Rui'an employers to associate, the absence of the former undermined the initiative to establish common standards - thus the collective-action problem persists. Such a dilemma will likely appear in other places and industries in China and perhaps in postsocialist countries more broadly.

One shortcoming of this research is that it does not integrate an analysis of the role of public policy in setting standards. Particularly in a context such as China, with its strong state and weak civil society, policy is likely to have a major impact on the development of labor relations. To take one recent example, beginning in 2013 the Guangzhou municipal government attempted to directly establish wage levels in the sanitation sector in response to recurrent labor unrest. This suggests that ineffectual unions may come to be sidelined by increasingly impatient local governments. Assessing 
the interaction between public policy, unions, and sectoral negotiation is a promising line of future inquiry.

As for future developments, unions throughout China must respond to demands from ACFTU leadership to increase the number of workers covered by collective contracts. Although Zhejiang unions are likely to respond to directives from the center through sectoral-level negotiation, unions in areas with higher levels of FDI will largely pursue enterprise-based collective negotiation. Since 2011, there have been attempts to establish sectoral negotiation in Guangzhou's electronics industry, although only at the district level. ${ }^{32}$ It seems unlikely that this and other ongoing experiments will be successful. It is clear that trade unions, employers, and governments in diverse regions are constructing distinct labor relations infrastructures in a process that is highly constrained by local economic conditions.

\section{References}

Behrens, Martin. 2004. New Forms of Employers' Collective Interest Representation? Industrielle Beziehungen 11: 77-91.

Bramall, Chris. 1989. The Wenzhou "miracle": An assessment. In Peter Nolan and Fureng Dong (Eds.), Market Forces in China: Competition and Small Business: The Wenzhou Debate, pp. 43-76. London: Zed Books.

Broadman, Harry G., and Xiaolun Sun. 1997. The Distribution of Foreign Direct Investment in China. World Bank.

Chan, Anita. 2001. China's Workers under Assault: The Exploitation of Labor in a Globalizing Economy, pp. xv, 249. Armonk, NY: M. E. Sharpe.

Chan, Chris King-Chi. 2010. The Challenge of Labour in China: Strikes and the Changing Labour Regime in Global Factories. London: Routledge.

Chan, Chris King-Chi, and Ngai Pun. 2009. The making of a new working class? A study of collective action of migrant workers in South China. China Quarterly 198: 287-303.

Chen, Calvin. 2008. Some Assembly Required: Work, Community, and Politics in China's Rural Enterprises. Cambridge: Harvard University Press.

Chen, Chunlai, Lawrence Chang, and Yimin Zhang. 1995. The role of foreign direct investment in China's post-1978 economic development. World Development 23(4): 691-703.

Chen, D., and J. Huang. 2008. Zhejiang wenlingshi tuixing hangye gongzi jiti xieshang zhidu de jingyan yu qishi (The experience and inspiration of Wenling's implementation of a collective wage negotiation system). Tianjinshi gonghui guanli ganbu xueyuan xuebao 16(3): 30-32.

Chen, Feng. 2003a. Between the state and labour: The conflict of Chinese trade unions' double identity in market reform. China Quarterly 176: 1006-28.

- 2003b. Industrial restructuring and workers' resistance in China. Modern China 29: 237-62.

Clarke, Simon. 2005. Post-socialist trade unions: China and Russia. Industrial Relations Journal 36(1): 2-18.

Clarke, Simon, Chang-Hee Lee, and Do Quynh Chi. 2007. From rights to interests: The challenge of industrial relations in Vietnam. Journal of Industrial Relations 49(4): 545-69.

Clarke, Simon, and Tim Pringle. 2009. Can party-led trade unions represent their members? Post-Communist Economies 21 (1): 85-101. doi:10.1080/14631370802663679.

\footnotetext{
${ }^{32}$ Luogang District Federation of Trade Unions. The district of Luogang has established a sectoral union federation. Accessed at http://gonghui.luogang.gov.cn/gz33cmsweb/CMShtml/xwzx/xwzw_gzdt /2011-7/13/15_27_20_110.html (August 2011).
} 
Cooney, Sean. 2007. China's labour law, compliance and flaws in implementing institutions. Journal of Industrial Relations 49(5): 673-86.

Crowley, Stephen. 2004. Explaining labor weakness in post-communist Europe: Historical legacies and comparative perspective. East European Politics and Societies 18(3): 394-429. doi: $10.1177 / 0888325404267395$.

Crowley, Stephen, and David Ost. 2001. Workers after Workers'States: Labor and Politics in Postcommunist Eastern Europe. Lanham, MD: Rowman \& Littlefield Publishers.

Eng, Irene. 1997. The rise of manufacturing towns: Externally driven industrialization and urban development in the Pearl River Delta of China. International Journal of Urban and Regional Research 21: 554-68.

Evans, Peter B. 1995. Embedded Autonomy: States and Industrial Transformation. Princeton, NJ: Princeton University Press.

Forster, Keith. 1990. The Wenzhou model for economic development: Impressions. China Information 5(53): 53-64.

Friedman, Eli. 2013. Insurgency and institutionalization: The Polanyian countermovement and Chinese labor politics. Theory and Society 42(3): 295-327. doi:10.1007/s11186-013 -9192-1.

Gallagher, Mary Elizabeth. 2002. Reform and openness: Why China's economic reforms have delayed democracy. World Politics 54(3): 338-72.

- 2005. Contagious Capitalism: Globalization and the Politics of Labor in China. Princeton, NJ: Princeton University Press.

Howell, Jude. 2008. All-China Federation of Trade Unions beyond reform? The slow march of direct elections. China Quarterly 196: 845-63.

Hsing, You-tien. 1998. Making Capitalism in China: The Taiwan Connection. New York: Oxford University Press.

Huang, Yasheng. 2003. Selling China: Foreign Direct Investment during the Reform Era. New York: Cambridge University Press.

Huang, Yasheng, and Tarun Khanna. 2003. Can India overtake China? Foreign Policy 137: 74-81.

Katz, Harry C. 1993. The decentralization of collective bargaining: A literature review and comparative analysis. Industrial and Labor Relations Review 47(1): 3-22.

Lau, Raymond W. K. 2003. The habitus and "logic of practice" of China's trade unionists. Issues and Studies 39(3): 75-103.

Lee, Chin Kwan 1995. Engendering the worlds of labor: Women workers, labor markets, and production politics in the South China economic miracle. American Sociological Review 60(3): 378-97.

1998. Gender and the South China Miracle: Two Worlds of Factory Women. Berkeley: University of California Press.

— 2007. Against the Law: Labor Protests in China's Rustbelt and Sunbelt. Berkeley: University of California Press.

Lichtenstein, Nelson. 2009. The Retail Revolution: How Wal-Mart Created a Brave New World of Business. New York: Metropolitan Books.

Lindbeck, Assar, and Dennis J. Snower. 2001. Centralized bargaining and reorganized work: Are they compatible? European Economic Review 45(10): 1851-75. doi:10.1016/S00142921(01)00086-1.

Liu, Alan P. L. 1992. The "Wenzhou model" of development and China's modernization. Asian Survey 32(8): 696-711.

Liu, J. 2011. Guangdong zhigong minzhu canyu sanshi nian. Beijing xingzheng xueyuan xuebao 6: 103-7.

Liu, Mingwei. 2010. Union organizing in China: Still a monolithic labor movement? Industrial and Labor Relations Review 64(1): 30-52.

Liu, Yia.-Ling. 1992. Reform from below: The private economy and local politics in the rural industrialization of Wenzhou. China Quarterly 130: 293-316.

Locke, Richard M. 1992. The demise of the national union in Italy: Lessons for comparative labor relations theory. Industrial and Labor Relations Review 45(2): 229-49.

Ma, Zhining. 2011. The ACFTU and Chinese Industrial Relations. New York: Peter Lang.

Marginson, Paul, Keith Sisson, and James Arrowsmith. 2003. Between decentralization and 
europeanization: Sectoral bargaining in four countries and two sectors. European Journal of Industrial Relations 9: 163-87. doi:10.1177/0959680103009002003.

Nee, Victor, and Sonja Opper. 2012. Capitalism from Below: Markets and Institutional and Change in China. Cambridge, MA: Harvard University Press.

Offe, Claus, and Helmut Wiesenthal. 1980. Two logics of collective action: Theoretical notes on social class and organizational form. Political Power and Social Theory 1: 67-115.

Pak, Chong-dong. 1997. The Special Economic Zones of China and Their Impact on Its Economic Development. Westport, CT: Greenwood.

Parris, Kristen. 1993. Local initiative and national reforms: The Wenzhou model of development. China Quarterly 134: 242-63.

Pearson, Margaret M. 1994. The Janus face of business associations in China: Socialist corporatism in foreign enterprises. Australian Journal of Chinese Affairs 31: 25-46.

Pringle, Tim. 2011. Trade Unions in China: The Challenge of Labour Unrest. Abingdon, UK: Routledge.

Pun, Ngai. 2005. Made in China: Women Factory Workers in a Global Workplace. Durham, NC: Duke University Press.

Pun, Ngai, Chris King-Chi Chan, and Jenny Chan. 2009. The role of the state, labour policy and migrant workers' struggles in globalized China. Global Labour Journal 1(1): 132-51.

Solinger, Dorothy J. 1999. Contesting Citizenship in Urban China Peasant Migrants, the State, and the Logic of the Market. Berkeley: University of California Press.

Taylor, Bill, and Qi Li. 2007. Is the ACFTU a union and does it matter? Journal of Industrial Relations 49(5): 701-15.

Thireau, Isabelle, and Linshan Hua. 2003. The moral universe of aggrieved Chinese workers: Workers' appeals to arbitration committees and letters and visits offices. China Journal 50: 83-103.

Traxler, Franz. 1993. Business associations and labor unions in comparison: Theoretical perspective and empirical findings on social class, collective action and associational organizability. British Journal of Sociology 44(4): 673-91.

— 1998. Collective bargaining in the OECD: Developments, preconditions and effects. European Journal of Industrial Relations 4(2): 207-26. doi:10.1177/095968019842004.

— 2003. Coordinated bargaining: A stocktaking of its preconditions, practices and performance. Industrial Relations Journal 34(3): 194-209. doi:10.1111/1468-2338.00268.

Tsai, Kellee S. 2002. Back-Alley Banking. Ithaca, NY: Cornell University Press.

Tseng, Wanda, and Harm Zebregs. 2003. Foreign direct investment in China: Some lessons for other countries. In Wanda Tseng and Markus Rodlauer (Eds.), China: Competing in the Global Economy, pp. 68-88. Washington, DC: International Monetary Fund.

Wang, S. 2004. Hangye zuzhi de cunzai jichu he quanli laiyuan: Dui wenzhou shanghui de shehui hefaxing kaocha (The origin of power and foundation of existence for industrial organizations: An investigation of the social legitimacy of Wenzhou employer associations). Zhonggong zhejiang sheng weidangxiao xuebao 2: 5-12.

Warner, Malcolm. 1995. The Management of Human Resources in Chinese Industry. Basingstoke, UK: Macmillian.

Wei, Yehua Dennis, Wangming Li, and Chunbin Wang. 2007. Restructuring industrial districts, scaling up regional development: A study of the Wenzhou model, China. Economic Geography 83(4): 421-44.

Wright, Erik Olin. 2000. Working-class power, capitalist-class interests, and class compromise. American Journal of Sociology 105(4): 957-1002.

Wu, G. 2004. Wenzhou shanghui zuoyong tuxiang: Qiangda minjian liliang zhutui jingji fazhan (Promotion of the function of Wenzhou employer associations: Strong civil power promotes economic development). Qiye jingji 11: 152-53.

Yu, Jianxing, Honghua Huang, and Liming Fang. 2004. Zai Zhengfu Yu Qiye Zhjian: Yi Wenzhou Shanghui Wei Yanjiu Duixiang (Between Government and Enterprise: Taking Wenzhou Employer Associations as a Research Object). Hangzhou: zhejiang renmin chubanshe.

Yu, J., Y. Xu, and H. Jiang. 2007. Wenzhou shanghui de liwai yu bu liwai: Zhongguo gongmin shehui de fazhan yu tiaozhan (The exceptionalness and unexceptionalness of Wenzhou employer associations: The development and challenges of civil society in China). Zhejiang daxue xuebao 37(6): 5-15. 
Yu, Xiaomin. 2008. Impacts of corporate code of conduct on labor standards: A case study of Reebok's athletic footwear supplier factory in China. Journal of Business Ethics 81: 513-29.

Zhang, J., and Y. Shi. 2012. Guanyu hangye jiti xieshang qingkuang de diaoyan baogao (Research report on the conditions of sectoral collective consultation). Journal of China Institute of Industrial Relations 26(4): 51-57.

Zhu, S. 2008. Zhejiang wenling hangye gongzi jiti xieshang diaocha (Investigation of Zhejiang's Wenling sectoral collective wage negotiation). Guangdong xingzheng xueyuan xuebao 20(6): 82-90. 